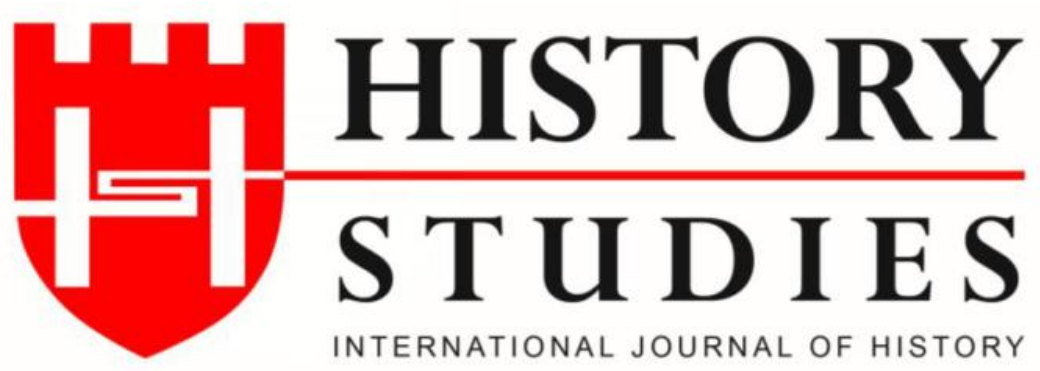

ISSN: 13094173 (Online) 1309 - 4688 (Print)

Volume 12 Issue 2, A Tribute to Assoc. Prof. Dr. İlknur Mangir Karagöz, April 2020

DOI Number: 10.9737/hist.2020.850

Araştırma Makalesi

Makalenin Geliş Tarihi: 12.02.2020 Kabul Tarihi: 06.04.2020

Atıf Künyesi: J. Özlem Oktay Çerezci, “Timurlu Dönemi Mimarisinde Sembolizm”, History Studies, Doç. Dr. İlknur Mangır Karagöz Armağanı, 12/2, Nisan 2020, s. 703-725.

\title{
Timurlu Dönemi Mimarisinde Sembolizm
}

\author{
The Symbolism of Timurid Period Architecture
}

\author{
Dr. J. Özlem Oktay Çerezci \\ ORCID No: 0000-0002-5345-1935
}

Mimar Sinan Güzel Sanatlar Üniversitesi

Öz:1370 yılında kurulan Timurlular, 15. yüzyılda gerek siyasi gerekse sanatsal anlamda çok önemli işlere imza atmışlardır. Yıkılana kadarki süreç zarfında genel anlamda İpek Yolu'nun ortasından geçtiği bölgede özellikle Semerkant, Herat, Isfahan'da mimari alanda kendilerini oldukça geliştirmişlerdir. Söz konusu yapılar çeşitli araştırmacılar tarafından çalışılmış ancak bunların sembolik anlamları üzerinde detaylı olarak durulmamıştır. Halbuki Timurlu mimari eserleri ve şehirleri, işlevsel özelliklerinin yanı sıra gerek plan gerekse süsleme ve boyutları açısından oldukça önemli bir takım sembolik anlamlar barındırmaktadır. Bu özelliklerden ilk göze çarpanı, yapıların hükümdarlığın ve hükümdarın gücünü, ihtişamını sergileme amaçlı, oldukça devasa boyutlara ulaşmış olmalarıdır. Timurlu dönemi bitkisel süslemelerinde bahar dalları, cennetin bir yansıması olarak görülebilir; kıvrımlı dallar ise geometrik süslemelerle birlikte yine sonsuzluk anlayışının pekiştirici unsurlarıdır. Sembolik anlamda dikkati çeken diğer nokta da şehirlerin ve mimari planların "dört ana yön" anlayışına göre düzenlenmesidir. Bu dönemin mimarisinde hayvan tasvirlerine ise çok fazla rastlanmaz. Bununla birlikte tasvir edilen hayvanlar ve mücadele sahnesi Türk sanatı ikonografisinde ve sembolizminde görmeye alışık olduğumuz hususları korumaktadır. Söz konusu araştırmamızda Timurlu dönemi mimarisi gerek plan gerekse mimariye bağlı süsleme programları, Orta ve İç Asya erken dönem Türk sanatı sembolizmi de göz önüne alınarak, sembolizm açısından örneklerle değerlendirilmeye çalışılacaktır.

Anahtar Kelimeler: Timurlu dönemi, mimari, sembolizm, plan, süsleme.

\begin{abstract}
The Timurids who were established in 1370, created many important works not only in political but in artistic area. Until their fall, they improved themselves in terms of architecture especially in Semerkand, Herat and Isfahan where Silk Road passes directly through this region. The cities and the architecture of Timurids were not only built for function but have some symbolical meanings in the terms of their dimensions and ornaments. One of their symbolic purposes is to show the power, wealth and magnificence of the ruler and the empire with their gigantic dimensions. The plant ornaments can be seen as reflection of heaven. The folded ornamental motifs, with the geometrical ones, are again symbolize the eternity. Another point that takes attention in the symbolism is the city and architectural plans of this period. They were designed according to the "four main directions". At Timurid Period architecture, the animal representations are rare. However,
\end{abstract}


the represented animals and animal combat scenes maintain the classical Turkish art iconography and symbolism such as power, sovereignty, sun and et various other meanings. In our research the plans and ornaments of architecture of Timurid period are tried to be evaluated from the point of symbolism.

Keywords: Timurid period, architecture, symbolism, plan, ornament.

\section{Giriş}

1336 yılında Şehr-i Sebz'de doğan Timur, Belh Şehri’nde Emir Hüseyin'i yenip 1370 yılında "Kürekân" ünvanını alır ve Semerkant'ta tahta oturur. ${ }^{1} Y$ ine aynı y1l Timur Maveraünnehir'de hemen hemen tüm emirlere hakimiyetini kabul ettirmiştir. 1371- 1404 yılları arasında Kuzey İran, Azerbaycan, Isfahan, Şiraz, Suriye gibi yerlere seferler düzenleyen Timur, 1402 yılında Yıldırım Bayezıt'1 Ankara'da yenilgiye uğratır. Timur'dan sonra tahta çıkan oğlu Şahruh (1404/5-1447) zamanında hükümet merkezi Semerkant’tan Herat'a geçer. Bu hükümdar ile Semerkant'ta vali olarak atadığı Uluğ Bey zamanında Horasan ve Maveraünnehir şehirleri önem kazanmıştır. Ayrıca Uluğ Bey'in Semerkant'ta bir rasathane kurdurması oldukça dikkate değerdir. Bu dönemde de Azerbaycan, Fergana toprakları ve Moğollar üzerine seferler düzenlenir.

15. yüzyılın ikinci yarısında yükseliş dönemi Semerkant'ta tahta oturan Ebu Said (14511469) zamanında devam etmiştir. Ancak sınırlar daralmaya başlamıştır. Diğer bir önemli Timurlu hükümdarı da 1468-1501 arasında Herat'ta hüküm sürmüş olan Hüseyin Baykara'dır. Hüseyin Baykara'nın ölümünden sonra oğulları Muzaffer Hüseyin ve Bediüzzaman birlikte hükümdar olurlarsa da kısa bir süre sonra Herat, Muhammed Şibâni tarafından ele geçirilir ve Timur hanedanı Semerkant'tan atılır. ${ }^{2}$ Tüm bu coğrafyaya baktığımızda Timurluların varlık gösterdiği toprakları, İpek Yolu'nun ortasından geçtiği bölge olarak belirtebiliriz (Şekil: 1). ${ }^{3}$ Söz konusu topraklarda 16. yüzyılın başına kadar olan süreçte Timurlular zamanında şehircilik önemli derecede gelişmiştir. ${ }^{4}$

Özellikle Timur, yenilgiye uğrattı̆̆ı topraklardaki sanatçıları, yapı ustalarını, bilim adamlarını hükümdarlığında değerlendirmiştir. Dolayısıyla Türk ve İran kültürünü kaynaştıran Timurlu döneminde Orta Asya'da Türk İslam kültürü gelişmiştir. Hükümdarlıkları süresince Timurlular çok önemli mimari eserler yapmışlardır; bunlar arasında cami, medrese ve türbeler başta gelmektedir. Ayrıca saraylar, ticaret yapıları ve rasathane gibi çeşitli yapılar da inşa etmişler, şehir planlamasına önem vermişlerdir. ${ }^{5}$ Ancak bu noktada belirtmek gerekir ki yapılar

\footnotetext{
${ }^{1}$ İsmail Aka, Timur ve Devleti, Türk Tarih Kurumu Yayınları, Ankara 1991, s. 6-7.

${ }^{2}$ A.g.e., s. $147-149$.

${ }^{3}$ Klaus Pander, "Timuroğullarının Orta Asya Mimari Sanatına Katkıları”, Türkler Ansiklopedisi, Yeni Türkiye Yayınları, Ankara 2002, s. 852-853.

${ }^{4}$ Mustafa Cezar, Anadolu Öncesi Türklerde Şehir ve Mimarlı, Türkiye İş Bankası Kültür Yayınları, İstanbul 1977, s. 429.

${ }^{5}$ İsmail Aka, "Timurlular” (1370-1506), Kuruluş ve Çöküş Süreçlerinde Türk Devletleri Sempozyumu Bildirileri (56 Kasım 2007), Sakarya Üniversitesi Yayınları, Sakarya 2008, s. 186.
} 
çok hızlı ve devasa boyutlarda yapıldığından bunların bir kısmı çok kısa sürede tahrip olmuştur. ${ }^{6}$

\section{Timurlu Dönemi Mimarisinde Devasa Boyutlar-Hükümdarın ve Hükümdarlığın Gücü}

Timurlu mimari eserleri ve şehirleri işlevsel özelliklerinin yanı sıra gerek plan gerekse süsleme ve boyutları açısından bir takım sembolik anlamlar barındırmaktadır. Söz konusu özelliklerden ilk göze çarpanı yapıların, hükümdarlığın gücünü ve ihtişamını sergileme amaçlı oldukça devasa boyutlara ulaşmasıdır. Bunu da "bizim iktidarımızdan şüphe ediyorsanız, inşâ ettiğimiz eserlere bakın" cümlesi ile açıkça belirtmektedirler. Ayrıca Şah-1 Zinde Külliyesi'nde yer alan 1376 tarihli Emir Hüseyin (Tuğlu Tekin) Türbesi'nin kitabesinde de "Benim sarayıma bir bak, Satürn (yıldızl) kendini onunla kıyaslayamaz" şeklindeki ifade de bu anlamı pekiştirmektedir. ${ }^{7}$ Başka bir deyişle Timurlu dönemi mimarisi, hükümdarın ve hükümdarlığın gücünün sergilendiği en önemli unsurdur. İbn Arabşah’tan edinilen bilgi az önce üzerinde durduğumuz detayları bir kez daha kanıtlamaktadır: Timurlu dönemi "saraylarının duvarları onların sefer ve zaferlerinin gösterildiği sahnelerle doluydu". ${ }^{\circ}$

Kubbeler ve kubbe kasnakları da benzer biçimde hükümdarllğın gücünün ve zenginliğinin

Volume 12

Issue 2

A Tribute

to Assoc.

Prof. Dr.

İlknur

Mangir

Karagöz,

April

2020

kanıtı yani bir statü sembolü olarak devasa boyutlardadır. Kubbeleri yükseltmek için zaman zaman çift çidarlı dediğimiz iç içe iki kubbeyi ve yüksek kasnakları kullanmışlardır (Şekil: 2 ab). Ayrıca taç kapılar anıtsallığın, ihtişamın sembollerinden biri olarak yükseltilmiş şekilde karşımıza çıkar. Örneğin, 1420 tarihli Uluğ Bey Medresesi taç kapısı 25 metrelik yüksekliğe sahip olup devasa kubbe ile boy ölçüşen önemli örneklerden biridir (Şekil: 3). Söz konusu kapılar aynı zamanda gündelik hayattan manevi dünyaya girişi temsil etmektedir.

\section{Gökyüzü ve Sonsuzluk}

Hükümdarlığın gücünün, sonsuzluk fikrinin daha da etkileyici olması için, döneminin zenginlik anlayışı ile de paralel olarak, mimarideki biteviye yani boş yer kalmayacak şekilde süslemeye oldukça önem verilmiştir. Bu noktada göksel ya da sonsuzluk ifadelerini taşıyan, mimaride sık sık karşımıza çıkan, çoğunluğu çeşitli çini teknikleri ile yapılan geometrik ve bitkisel süslemelere değinmek gerekmektedir. ${ }^{9}$ Bu biteviye süslemeler yukarıda da değinildiği gibi bir taraftan devasa ölçülere sahip yapılardaki kusuru kapatırken diğer taraftan devletin gücünü ve sonsuzluk anlayışını sergilemekteydi (Şekil: 3-6). Timurlu dönemi mimarisinin

\footnotetext{
${ }^{6}$ Robert Hillenbrand, "Aspects of Timurid Architecture in Central Asia”, Utrecht Papers on Central Asia. Proceedings of the First European Seminar of Central Asian Studies held at Utrecht, 16-18 December 1985, (eds. M.van Damme and H.Boeschoten ) Utrecht, 1987, s. 255-286; İsmail Aka, "Mirza Şahruh Zamanında (1405-1447) Timurlularda İmar Faaliyetleri”, Belleten, XLVIII, 1984, s. 296; G. A. Pugaçenkova, "Transoxania and Khurasan", History of civilizations of Central Asia. The age of achievement: A.D. 750 to the end of the fifteenth century, Volume IV. Part Two, (ed. Bosworth C.E., Asimov M.S.) Paris, UNESCO Publishing, 2000, s. 510.

${ }^{7}$ Pander, a.g.m., s. 853-854.

8 Detaylı bilgi için bkz. İbni Arabşah, Acâibu'l Makdûr (Bozkırdan Gelen Bela), çev. Ahsen Batur, Selenge Yayınevi, İstanbul 2012; İsmail Aka, "Göçebelikten Rönesansa Bir Türk Devleti: Timurlular”, Türk Kültürü, S. 452, Aralık 2000, Y1l XXXVIII, s. 718.

${ }^{9}$ Seyfi Başkan, "Timurlu Çağı Türbe Mimarisi Hakkında”, Sanat Tarihi Dergisi, Cilt XXII, Sayı 1, Nisan 2013, s. 1-23; Seyfi Başkan, “Timurlu Mimarlığında Çini Süsleme Hakkında Bir Değerlendirme”, Turkish Studies, 9/10, Fall 2014, s. 77-95.
} 
vazgeçilmez geometrik süslemeleri arasında içiçe geçen dügümler, eşkenar dörtgenler, çok kollu yıldız formları, çokgenler başta gelmektedir. Tüm bu geometrik süslemeler sonsuzluk hissi uyandırmakta ve Kurân-1 Kerim Saffat Sûresi, 6. Ayet'te geçen "Biz yakın göğü, bir süsle, yıldızlarla süsledik" ifadesi ile örtüşmektedir. Tarihçi Abdürrezzak Semerkandî ise konumuzla ilgili olarak bu yapının süslemelerinden şöyle bahseder: "dokuz gök katının.... temsilerini anlatır". ${ }^{10}$

Timurlu kubbeleri; gerek boyutu gerekse turkuvaz veya mavi rengi ve heybetli görünümleri (genelde mozaik-çini olarak) ile bu bağlamda bir takım sembolik anlamları bünyesinde barındırmaktadır. ${ }^{11}$ Gur-i Mir Türbesi'ndeki 34 metreyi bulan yüksekliği ile turkuvaz renkli kubbe, göğe belki de sonsuzluğa ulaşmanın ifadelerinden biri olsa gerekir (Şekil: 4). Burada yer alan bir kitabede "Allah'ın ebedi olması" ile ilgili tanım konuyla bütünlük arz eder. Başka bir deyişle kubbeler Göksel İlahi’yi sembolize eder. Bu anlayışta yapılmış Timurlu dönemine ait pek çok mimari eser karşımıza çıkmaktadır. Bunlardan biri de Bibi Hanım Camii'dir; 44 metre yüksekliğe sahip devasa soğan kubbesi mavi renktedir (Şekil: 5).

Kubbelerin içindeki süslemeler de benzeri ifadeyi destekler niteliktedir. Gerek camilerin gerekse kubbeli diğer mimari eserlerin kubbe içlerinde sonsuzluğa ve gökyüzüne, yıldız sistemlerine başka bir deyişle "evren"e gönderme yapan içiçe geçen yıldızlar, geometrik desenler dikkat çekmektedir. ${ }^{12}$ Kasım b. Abbas Türbesi iç mekanında, sonradan bir takım yenilemeler olsa da, mavi, beyaz ve yeşil renk çini birlikteliği sonsuzluk ve gökyüzü sembolizmine işaret eder (Şekil: 6). ${ }^{13}$ Konuyla bağlantılı olarak Herat Gevher Şâd Türbesi kubbe altına bakıldığında kesişen, iç içe geçen geometrik düzenleme sayesinde bir yandan sonsuzluk fikri diğer yandan çokgen içinde daire ile aşağıda değineceğimiz evren tasarımı görülmektedir (Şekil: 7).

Sivri kemerlerde, kemer alınlıklarında, cepheleri sonlandıran köşe kulelerinde ve cephelerde panolar içinde satrançlı Kufi olarak "Allah", "Muhammed" ifadeleri pek çok kez uygulanmıştır. Bunlarla birlikte yine sonsuzluk anlayışının tamamlayıcısı olarak iç içe geçen geometrik desenler, silmeler, çokgen kollu yıldızlar kullanılmıştır. Bunu dönemi içinde yorumladığımızda ise her şeyin aynı kökten gelmesi ifadesini dile getirmek yanlış olmayacaktır (Şekil: 8). Bu noktada değinmekte fayda vardır ki koyu lacivert, firuze ve beyaz tonlarının kullanımı tesadüf değildir; tüm bu renklerin de bir sembolizmi bulunmaktadır. Mavi, göğü anımsattığından dolayı gök unsuruna işaret etmektedir. Beyaz ise bilindiği üzere temizliğin, saflığın, ululuğun timsallerindendir. Firuze olarak da adlandırılan turkuaz renk yine benzer biçimde göğe, sonsuzluğa gönderme yapan diğer bir unsurdur.

\footnotetext{
${ }^{10}$ Frédérique Beaupertuis-Bressand, “Alim Emir Yıldızları İlhak Ediyor”, Semerkand 1400-1500 Timur'un Vaha Kenti: Bir İmparatorluğun ve Rönesans'in Kalbi, derl. Vincent Fournau, çev. Ali Berktay, Sena Yayınevi, İstanbul 2005, s. 141.

${ }^{11}$ Bernard O’Kane, Timurid Architecture in Khurasan, Mazdâ Publishers, California 1987, s. 108.

12 Gülru Necipoğlu, "Geometric Design in Timurid/Turkmen Architectural Practice", Thoughts on a Recently Discovered Scroll and its Late Gothic Parallels, Iran and Central Asia in the Fifteenth Century, ed. Lisa Golombek - Maria Subtelny, Leiden, Brill 1992, s. 53.

${ }^{13}$ Seyfi Başkan, "Semerkand Şah-1 Zinde Yapıları", Vakıflar Dergisi, S. 37, Haziran 2012, s. 145.
} 
Timurlu mimarisinde taçkapıların kemer alınlıklarında rozet ya da güneş formları çok kullanılmıştır (Şekil: 3, 9). Ay ve güneş Türkler için erken devirlerden itibaren önemli birer kült olmuşlar ve hükümdar ile ilişkilendirilmiştir. Örneğin, Göktürk dönemi sikkelerinde bunun kanıtlarını bulmak mümkündür (Şekil: 10); Taşkent'ten ele geçen Göktürk dönemi sikkeleri üzerinde betimlenen kağanın başına yakın kısımlarda genelde hilal ve yıldız tasvirleri görülmektedir. ${ }^{14}$ Uluğ Bey Rasathanesi hakkında da şu ifade ise yine gökyüzü sembolizmi açısından dikkat çekmektedir: "dokuz gögü̈n dereceler, dakikalar, saniyeler hattâ saniyenin onda biri ile gögün dokuz katının tasvirlerinin bulunduğu...". ${ }^{15} \mathrm{Bu}$ noktada göğün dokuz katının bulunması gibi ifadeler, erken devir Türklerinin inanç sisteminindeki bir takım noktaları hatırlatmaktadır. Örneğin Altaylı şamanların Ülgen'e ulaşmak için yaptıkları yolculukta dokuz dallı kayın ağacını kullanarak göğe ulaştıklarına inanılmaktaydı. ${ }^{16}$

\section{Cennetin Yansımaları}

Benzeri anlayışa paralel biçimde yukarıda değinilen mimari eserler dışında Uluğ Bey Rasathanesi'nde de hissedildiği üzere sırlı tuğlalardan süslemeler ile bitkisel ve geometrik desenlerden oluşan çini mozaikler adeta cennetin tarifini yapar. Özellikle Timurlu dönemi bitkisel süslemelerindeki bahar dalları, cennetin bir yansıması olarak görülebilir; kıvrımlı dallar ise geometrik süslemelerle birlikte yukarıda değindiğimiz sonsuzluk ve cennet anlayışının pekiştirici unsurlarıdır. Ayrıca türbe girişlerindeki kemer alınlıklarında yer alan bu tarz bitkisel süslemeler dünya ya da hayat ağaçlarının bir izdüşümü belki de cennete giden birer yol olarak düşünülebilir. ${ }^{17} \mathrm{Bu}$ bağlamda aşağıda bahsedeceğimiz simetrik, dörtgen plana göre

Volume 12

Issue 2

A Tribute

to Assoc.

Prof. Dr.

İlknur

Mangir

Karagöz,

April

2020 düzenlenmiş yeşil bahçeler ve bunlar içinde kare bölmelerden geçen su kanalları, cennetin başka bir ifadesidir. ${ }^{18}$ Uluğ Bey’in mezar taşındaki “... Onun buraya inmesi cennet bahçelerini hoşnut, cennet yapılarının bostanlılarını memnun etmiştir..." ş̧eklindeki ifade konuyla bağlantılı unsurlar içermektedir. ${ }^{19}$

Cennet kavramının mimariye yansıması örneklerine "üç girişli ve kubbeli" yapılar da dahil edilmektedir. Buna işaret eden eserlerden biri Bibi Hanım Camii’dir (Şekil: 5). Bu yapıyı Miraçnâme, varak 45v. "Hz. Muhammed'in Cennet Kapılarına Varışı" (Herat 1436-37) sahnesi (Şekil: 11) ile karşılaştırabiliriz. İkisine de düz bir zemin olarak baktığımızda, her birinde kubbe bulunan girişler görülmektedir. Minyatürde, yapıdaki ibadet kısmına girişi temsil eden orta giriş diğer ikisinden farklı ele alınmıştır. Bahsedilen iki giriş yivli çini-mozaik soğan kubbeye sahipken ana giriş altın rengi soğan kubbe ile temsil edilmiştir ve sağır nişin sivri

\footnotetext{
${ }^{14}$ Gaybullah Babayar, Köktürk Kağanlı̆̆ Sikkeleri Kataloğu, TíKA Yayınları, Ankara s. 90.

${ }^{15}$ Aleksandr Yakubovskiy, Timur ve Timuriler Devrinde Semerkand, çev. Sabur Rasol, yayına haz. İlyas Kemaloğlu, Türk Tarih Kurumu Yayınları, Ankara 2018, s. 63.

${ }^{16}$ Yaşar Çoruhlu, Türk Mitolojisinin Anahatları, Kabalcı Yayınevi, İstanbul 2010, s. 29, 207-212.

17 Lisa Golombek vd., The Timurid Architecture of Iran and Turan, vol. 1, Princeton University Press, Princeton1983, s. 208.

${ }^{18}$ Stephen F. Dale, The Garden of the Eight Paradises: Babur and the Culture of Empire in Central Asia, Afghanistan and India (1483-1530), Cambridge University Press, Brill Leiden-Boston 2004, s. 463.

${ }^{19}$ A. A. Semenov, “Gur-i Emir ve Türbesinde Timur'un ve Ahfadının Mezar Kitabeleri”, Makaleler ve İncelemeler (Abdülkadir İnan), Türk Tarih Kurumu Yayınları, Ankara 1968, s. 603.
} 
kemer iç kısmında çini süslemeler dikkati çeker. Bu özellikleri ile cennet kapısını gösteren minyatür, mimari esere oldukça benzemektedir. ${ }^{20}$

Plan olarak aşağıda bahsedeceğimiz dört yön ve bununla bağlantılı sekiz "sekiz cennet" (hasht-bihisht) kavramı mimari ile ilişkili çeşitli elemanlarda da mevcuttur. Örneğin Gur-i Mir'in ahşap kapılarından biri üzerinde benzer bir anlam yer almaktadır. Merkezde yer alan dört yön tasviri bir yandan sekiz cennete ulaşmak için geçilmesi gereken dört kapıyı diğer yandan hava, toprak, su, ateş unsurları ile kozmolojik ifadeyi bünyesinde barındırmaktadır. ${ }^{21}$ Bu noktada, "sekiz cennet" kavramı dahilinde süslemede karşımıza çıkan sekizgen ve sekiz kollu yıldızları da değerlendirmek gerekmektedir (Şekil: 12).

\section{Dört Ana Yön-Merkeziyetçilik}

Sembolik anlamda dikkati çeken diğer bir nokta da "dört ana yön" anlayışına göre şehirlerin ve mimari planların düzenlenmesidir. ${ }^{22}$ Dört ana yön simgesi Türklerde çok erken devirlerden beri süregelen en önemli sembollerden biridir. Dört ana yön şeması Türklerde merkeziyetçilik dolayısıyla mutlak hakimiyeti de ifade eder. $\mathrm{Bu}$ yüzden örneğin saray gibi yönetime ait yapıların şehir merkezinde inşa edilmiş olması tesadüf değildir. Zira, yönün merkezinde yer aldığı düşünülen ve kutsal olarak kabul edilen "dünya ağacı" ile bu yapılar arasında bir bağ da kurulabilir. 1514 yılında Kızılsu ve Tümen Irmağı’nın birleştiği alanda kurulan Yeni Kaşgar şehri böyle bir anlayışın izlerini taşımaktadır. Şehrin dört yöne açılan dört kapısı bulunmaktadır. Ayrıca Buhara, Semerkant, Meşhed ve Herat gibi merkezden dişa doğru gelişen şehirler de bu anlamda ele alınabilir. Örneğin Ebu Said Mirza (1458-1468) ve Hüseyin Baykara (1469-1506) dönemlerinde başkent olan Herat'ta birbirini dikine kesen caddelerden ve dikdörtgen ya da kare parsellere ayrılmış bina düzenlemelerinden bahsedilmektedir (Şekil: $13)^{23}$

Mimari anlamda da Timurlu dönemi eserlerinin simetrik olmasına özen gösterilmiştir. Çekirdek etrafında gelişen dört ya da sekiz bölümlü mekanlar ortada birleşerek merkeziyetçilik duygusunu vurgulamaktadır. ${ }^{24}$ Avlulu-dört eyvanlı plana sahip, günümüze gelen mimari örnekler arasında Türkistan Hoca Ahmed Yesevi Külliyesi (1394-99) (Şekil: 14), Semerkant Bibi Hanım Camii (1398-1405) (Şekil: 15), Meşhed Gevher Şah Camii (1416-18), Buhara Kaluyan Camii (1430) başta gelmektedir. Benzeri plan şemasına sahip diğer bir yapı grubu da medreselerdir. Semerkant Registanı'ndaki medreseler, mesela, Semerkant Uluğ Bey Medresesi kareye yakın avlulu, avlu etrafında dört eyvanlı, eyvanlar arası revaklı yapısı ile tam bir dört yön sembolü olarak karşımıza çıkar. Ayrıca adı geçen yapının köşelerinde merkezi planlı,

\footnotetext{
${ }^{20}$ Elena Paskaleva, "The Bibi Khanum Mosque in Samarqand: Its Mongol and Timurid Architecture", The Silk Road, V.10, 2012, s. 90.

${ }^{21}$ Başak Burcu Tekin, Timur Döneminde Mimari Bezeme Olarak Ahşap Kullanımı, (Hacettepe Üniversitesi Sosyal Bilimler Enstitüsü Yayınlanmamış Yüksek Lisans Tezi), Ankara 2000, s. 82.

${ }^{22}$ Ara Altın, "Orta Asya Türk Sanatı ile Anadolu'da Selçuklu ve Beylikler Devri Mimarisi”, Mimar Başı Koca Sinan, Yaşadı̆̆ Çăg ve Eserleri, Kendi Yayını, İstanbul 1988, s. 34.

${ }^{23}$ Cezar, a.g.e., s. 450; Gönül Cantay, "Emir Timur Devleti'nde Mimari”, Ölümünün 600. Yılında Emir Timur ve Mirası Uluslararası Sempozyumu, 26-27 Mayıs 2005, Bildiriler, Doğu Kütüphanesi, İstanbul 2007, s. 237.

${ }^{24}$ Lisa Golombek - Ebba Koch, "The Mughals, Uzbeks and the Timurid Legacy", A Companion to Islamic Art and Architecture, From the Mongols to Modernism, Ed. Finbarr Barry Flood and Gülru Necipoglu, vol. 2, Wiley Blackwell, Oxford 2017, s. 821. 
kubbeli mekanlar ve yine dört köşesinde silindirik minare bulunmaktadır (Şekil: 16). Benzeri plan şeması Buhara Uluğ Bey Medresesi (1420), Meşhed Do Dar Medresesi (1439) gibi mimari eserlerde tekrarlanmıştır. Dört yöne işaret eden plan yapısı olarak türbe mimarisine baktığımızda Gur-i Mir Türbesi (Şekil: 17) öne çıkar. ${ }^{25}$ Kare avlu etrafında anıtsal bir taç kapı ve üç kenarda işlevsel mekanların oluşturduğu bu kuruluş dört ana yönün mimaride ne derece yoğun kullanıldığının kanıtlarından biridir. Bu bağlamda kasnaklar ve dış cephede karşımıza çıkan Hz. Ebubekir, Hz. Ömer, Hz. Osman, Hz. Ali" olarak dört ad ile bunlara eşlik eden "Allah, Muhammed" isimlerini de unutmamak gerekir.

Aynı anlayışın günümüze gelemeseler (bir kaç kalıntı hariç) ${ }^{26}$ de özellikle Timur ve Eleğ Bey tarafindan Semerkant yakınlarında yapılan bahçe düzenlemelerinde devam ettiğini söylemek mümkündür. ${ }^{27}$ "Çahar Bag" olarak bilinen Timurlu bahçeleri dikdörtgen planlıdır ve su kanallarıyla simetrik kare bölmelere ayrılmıştır. ${ }^{28}$ Bu konuda İspanyol elçi Clavijo ve Zafernâme bize 1şık tutmaktadır. ${ }^{29}$ Bunlardan edinilen bilgilere göre Bağ-1 Dilguşâ'nın her kenarının ortasında birer kapı yer almaktaydı, dört köşesinde ise çiniyle kaplı birer kule ve ortasında da bir köşk bulunuyordu. Benzeri bahçe tasarımları Bağ-1 Nev ve Bağ-1 Behişt için de geçerliydi. Hatta Bağ-1 Nev içinde bir de dört yön planlı sarayın varlığından bahsedilmekteydi. ${ }^{30}$ Yine Semerkand'da kare formlu bahçenin merkezinde köşk tasarımı Timurlular için karakteristik olmuştur. ${ }^{31}$ Tüm bu mimari eserlere baktığımızda merkeziyetçilik, mutlak güç fikrinin dört yön plan şemasından başka bir unsur ile ifade edilemeyeceği açıktır. Dört kavramı ile ilgili Babür'ün eserinden aşağıdaki detay bu anlamda oldukça dikkat çekmektedir: "Kûhek Tepesinin garp tarafindaki eteğinde Băg-ı Meydan adlı bir bahçe ve bu bahçenin ortasında, Çihil-Sütûn dedikleri büyük bir bina yaptırmıştı. İki katlı ve sütunlar tamamen taştan olan bu binanın dört köşesine dört tâne, minareye benzer, burç konulmuştu. Üst katın dört tarafi ayvan olup, sütunları taştı. Ortasında dört köşseli bir oda vardı". ${ }^{32}$

Yukarıda da değinildiği üzere söz konusu kavram Türk kültüründe erken devirlere dayanmaktadır. Asya Hunlarında örneğin Moğolistan Aimak Töv'de (Chüret dov) dört ana yön anlayışına sahip bir kent ve bunun tam ortasında dört köşeli bir saray yapısı bulunmaktaydı. Özellikle Göktürk şehirciliğinde ve mimari yapılarında söz konusu durum karşımıza

25 Jean-Paul Roux, Aksak Timur İslamın Kutsal Savaşçısı, çev. Ali Rıza Yalt, Milliyet Yayınları, İstanbul 1994, s. 273.

${ }^{26}$ Wrawick Ball, "The Remains of a Monumental Timurid Garden outside Herat", East and West, vol.31. No.1/4, Aral1k 1981, s. 79-87.

27 A. R. Mukhamejanov, "Natural Life and the Manmade Habitat in Central Asia", History of Civilizations of Central Asia. The age of achievement: A.D. 750 to the end of the fifteenth century, Volume IV, Part Two, ed. Bosworth C.E., Asimov M.S., UNESCO Publishing, Paris 2000, s. 293.

${ }^{28}$ Mustafa Şahin, "Timurlular Döneminde Herât'ta Sivil Mimari”, Studies of the Ottoman Domain, Cilt 6, Sayı 11, Ağustos 2016, s. 90.

${ }^{29}$ Clavijo, Timur Devrinde Kadis'ten Semerkand'a Seyahat, çev. Ömer Rıza Doğrul, Köprü Kitapları, İstanbul 2016, s.165-175; Clavijo, Embassy to Tamerlane: 1403-1406, çev. Guy le Strange, George Routledge and Sons Ltd, London 1928, s. 218-236; Şerefüddin Ali Yezdi, Emir Timur (Zafernâme), çev. D. Ahsen Batur, Selenge Yayınları, İstanbul 2013, s. 172, 270, 274-275.

${ }^{30}$ Z. Kenan Bilici, “Asya Rönesansı: Timurlu Çağı'nın Mimarlık Mirasını Anlamak”, Ankara Üniversitesi Sosyal Bilimler Dergisi, 9 (2), 2018, s.7.

${ }^{31}$ Lisa Golombek, "The Gardens of Timur: New Perspectives", Muqarnas, S. 12, s. 138.

${ }^{32}$ Hayrunnisa A. Akbıyık, "Timurluların Bilim ve Sanata Yaklaşımları ve Bazı Son Dönem Sanatkârları", Bilig, Vol. 30, Yaz 2004, s. 157. 
çıkmaktadır. ${ }^{33}$ Tanrı Dağları eteklerinde kurulan, tek girişe sahip, dikdörtgen planlı Göktürk dönemine ait Şirdak Beg Kalesi (Şekil: 18) bu anlamda önemli bir örnektir.

Dört ana yön sembolizminin Türklerde ne derece güçlü olduğunun kanttlarından biri de Kültigin Yazıtı'nın kuzey cephesinde yer almaktadır:

"Buyruk beyleri Otuz. Dokuz Ŏguz beyleri, milleti!...

bu sözümü iyice işit, sağlamca dinle; ileri (doğuda)

gün doğusuna, beri (güneyde) gün ortasina, geri

(batıda) gün batısina, yukarl (kuzeyde) gece ortasina

doğru (olan yerlerin) bu içindeki millet(ler) hep bana

itaat eder...". ${ }^{34}$ Burada ayrıca hükümdarlık, merkeziyetçilik anlayışı da görülmektedir ki söz konusu anlayış da Timurlu Dönemi mimarisinde yükselen kubbeler, oranlar ve plan şeması ile örtüşmekte ve pek çok kez tekrarlanmaktadır. Dolayısıyla Timurlu mimarisi de kendi kültürel hafızasında yer eden bu unsurları sanat eserlerinde kullanmıştır diyebiliriz.

\section{Evren Sembolizmi}

Dört sayısı aynı zamanda, dört temel unsuru yani hava, toprak, su ve ateşi sembolize eder. Bir bakıma dört, dünyanın yapı taşıdır ve evren (kozmos)dir. ${ }^{35}$ Erken devir Türklerine göre yeryüzü dikdörtgen ya da dörtgen şeklindeydi. Bu dikdörtgen içindeki daire ise gökyüzünü ifade ederdi. Bu noktada Timurlu mimarisindeki dört eyvanlı avlulu, merkezi kubbeli plan şemasının öz önce değindiğimiz kare içinde daire tasarımı ile örtüştüğüne dikkat çekmek gerekmektedir. Yani Timurlu dönemine ait pek çok mimari eser evren şemasını anımsatmaktadır. Türklerde bu anlayışın oldukça köklü bir geçmişi vardır. Örneğin Okunyev kültürü taş heykellerinde evren şeması "kare içinde daire"dir (Şekil: 19). Bu tasarım gerek konumuz olan Timurlu mimarisinde gerekse Osmanlı dönemi mimari eserlerinde hatta sonrasında takip edilebilmektedir. ${ }^{36}$ Ayrıca Orta ve İç Asya'da evren yani kozmosun bir yansıması olarak görülen yurt tipi çadır ile kubbe arasında önemli bağlantılar da kurmak mümkündür. Bu başlık altında yukarıda değindiğimiz biteviye geometrik süslemeleri de anmak gerekir; iç içe geçen geometrik süslemeler bir yandan sonsuzluğa bir yandan evren kavramlarına işaret etmektedir.

\section{Timurlu Mimarisinde Hayvan Sembolizmi}

Timurlu Dönemi mimari süslemesinde karşılaştı̆̆ımız sembolizmde hayvan tasvirleri de bulunmaktadır. Semerkant'daki Nadir Divan Beg Medresesi ve Şir Dor (Dar) Medresesi taç kapı alınlıklarında ${ }^{37}$ "hayvan kovamala sahnesi”,38 yer alır. Registan'daki Şir Dar Medresesi taç

\footnotetext{
${ }^{33}$ Yaşar Çoruhlu, Erken Devir Türk Sanatı (İç Asyada Türk Sanatının Doğuşu ve Gelişimi), Kabalcı Yayınevi, İstanbul 2017, s. 87, 154-158

${ }^{34}$ H. N. Orkun, Eski Türk Yazıtları, Türk Dil Kurumu Yayınları, Ankara 1987, s. 22.

${ }^{35}$ Çoruhlu, a.g.e., 2010, s. 89

${ }^{36}$ N. Çiçek Akçıl Harmankaya, "Mimar Sinan Camilerinde Sembolizm Üzerine Bir Değerlendirme", Sanat Tarihi Y1llığ1, S. 27, Ankara 2018, s. 11-13.

${ }^{37}$ Gözde Ramazanoğlu, Orta Asya'da Türk Mimarisi, Türk Tarih Kurumu Yayınları, Ankara 1998, s. 111, 121.
} 
tapı köşesinde geyik kovalayan kaplan, sırtında insan yüzlü güneş tasviri ile karşımıza çıkar (Şekil: 20). Bu dört ayaklı yırtıcı, gövdesi üzerindeki çizgilerden dolayı kaplan olarak algılanmakla birlikte dikkatli bakıldığında ensesinde yelenin varlığı görülmektedir. Başka bir deyişle onu aslan olarak yorumlamamızı sağlar. Bununla bağlantılı biçimde Timur'un arma olarak güneş diski üzerindeki bir aslanı kullandığı düşünülmektedir. Ayrıca Gur-i Mir Türbesi'nde yer alan Timur'un mezarını örten mermer üzerindeki kitabede Timur'un soyunun Tanrı'nın aslanı Galip Ali bin Ebi Talib'den geldiğinden bahsedilmektedir. Benzeri bir tanım Timur'un oğlu Miranşah'ın türbesindeki mezar kitabesinde yer almaktadır. ${ }^{39} \mathrm{Bu}$ noktada belirtmek gerekir ki "Güneşin Efendisi” ifadesi Türklerde çok erken devirlerden itibaren kullanılmaktayd1. ${ }^{40}$

Buhara Nadir Divan Begi Medresesi'nde ise zümrüd-ü anka tarafından yakalanmış bir toynaklı hayvanın tasvir edildiği bir sahne yer almaktadır (Şekil 21). Alınlığın her iki köşesinde de aynı sahne işlenmiştir ve bu gerçeküstü hayvanlar avlarını, ortalarında bulunan güneşe doğru yukarıya taşımaktadır. Ayrıca muhtemelen Şeyh Cemaleddin'e ithaf edilen ve depremde oldukça hasar gördüğü için günümüze gelemeyen Kale Camii (1457) cümle kapısı üzerindeki kemerde bulunan mavi zemin üzerine siyah-beyaz renkte tasvir edilen iki ejderhanın da varlığı bilinmektedir. ${ }^{41}$ Tüm bu süslemeler aslında bozkır kültürü etkisinin izlerinin tamamen silinmediğinin kanıtlarındandır. ${ }^{42}$

Böyle tasvirlerin medresede betimlenmiş̧ olmaları, bilgeliğin cehaleti karşısında üstünlüğü şeklinde düşünülebilir. ${ }^{43} \mathrm{Bu}$ düşünceyi Şir Dar Medresesi'ndeki kaplanın sırtında bulunan güneş tasviri de destekler. Güneş ve aslanın bir arada yer aldığı durumlarda "bilgelik" ve "adil devlet" sembolleri öne çıkar. Bunlara ek olarak hayvan mücadele ve kovalama sahneleri, gökyer kavramlarının yanı sıra zafer-yenilgi, güçlülük-zayıflık, erkek-dişi, iyi-kötü, aydınlıkkaranlık, vb. zıt kavramlarla da ilişkilendirilmektedir. Tüm bu zıt kavram çiftlerinden olumluya işaret eden ve kazanan her zaman güçlü özellikleri taşıyan avcı yani yırtıcı hayvan olmuştur. Son olarak belirtmek gerekir ki söz konusu sahneler aynı zamanda bir nevi tılsım görevini de üstlenmişlerdir. ${ }^{44}$

\section{Sonuç}

Timurlu döneminde çok çeşitli yapı türlerine ve bunlara bağlı süsleme programlarına rastlamak mümkündür. Yapı türleri arasında cami, türbe, medrese başta gelmektedir. Ayrıca rasathaneye ve pek çok bahçeye sahiptirler. Aynı zamanda şehir planlamasına önem vermişlerdir. Çoğu belli bir düzene göre yapılan söz konusu yapıların gerek plan gerekse

38 J. Özlem Oktay Çerezci, "Türk Sanatında Yırtıcı Dört Ayaklı Hayvan-Toynaklı Hayvan Mücadelesi Üzerine”, Türk Dünyası Araştırmaları, S. 214, Şubat 2015, s. 75.

${ }^{39}$ Semenov, a.g.m., s. 592, 607

${ }^{40}$ Roux, a.g.e., s. 231-233; Yuriy F. Buryakov, "Timur, Timurlular ve Bozkırın Türk Göçebeleri”, Türkler Ansiklopedisi, Yeni Türkiye Yayınları, Ankara 2002, s. 536.

${ }^{41}$ Pander, a.g.m., s. 806.

${ }^{42}$ Buryakov, a.g.m., s. 538

${ }^{43}$ Oktay Çerezci, a.g.m., s. 11-12.

${ }^{44}$ Yaşar Çoruhlu, Türk Sanatında Hayvan Sembolizmi, Kömen Yayınları, Konya 2014, s. 163-173; T. N. Troitskaya, "Tsen Terzaniya v Skifo-Sibirskom i Hunno-Sarmatskom İskusstve", Vestnik Arheologii, Antropologii i Etnografii, Vol. 1, 1997, s. 35. 
süsleme açısından bir takım sembolik anlamlar içerdikleri ortadadır. Bunları hükümdarın ve hükümdarlığın gücü, gökyüzü ve sonsuzluk, evren, cennetin yansıması, dört ana yönmerkeziyetçilik ve hayvan sembolizmi olarak 5 ana başlık altında toplamak mümkündür. Timurlu dönemi mimarisi hükümdarın ve hükümdarlığın gücünün sergilendiği en önemli unsurdur. Kubbeler ve kubbe kasnakları adeta bir statü sembolü halinde devasa boyutlara ulaşmıştır. Taç kapılar da anıtsallığın, ihtişamın sembollerinden biri olarak karşımıza çıkar. Buna paralel biçimde, mimarideki biteviye süslemeye oldukça önem verilmiştir. Bu noktada göksel ya da sonsuzluk ifadeleri olarak, mimaride sık sık karşımıza çıkan, çoğunluğu çeşitli çini teknikleri ile yapılan geometrik ve bitkisel süslemeler başta gelir. Bu biteviye süslemeler yukarıda da değinildiği gibi bir taraftan devasa ölçülere sahip yapılardaki kusuru kapatırken diğer taraftan devletin gücünü ve sonsuzluk anlayışını sergilemekteydi. Özellikle Timurlu Dönemi bitkisel süslemelerindeki bahar dalları, cennetin bir yansıması olarak görülebilir. Kıvrımlı dallar, geometrik süslemelerle birlikte değindiğimiz sonsuzluk ve cennet anlayışının pekiştirici unsurlarıdır. Bu noktada bir tasvirin birçok başlık altında değerlendirileceğine değinmekte fayda vardır. Örneğin iç içe geçen geometrik süslemeler bir yandan sonsuzluğa bir yandan evren kavramlarına işaret etmektedir.

Dört ana yön şeması ise Türklerde merkeziyetçilik dolayısı ile mutlak hakimiyeti ifade eder. Sadece Timurlu mimarisi için değil genelde Türk İslam dönemi yapıları için avlulu-dört eyvanlı plana sahip, günümüze gelen örnekler bu bağlamda çok önemlidir. Dört sayısı aynı zamanda dört temel unsuru yani hava, toprak, su ve ateşi sembolize eder. Bir bakıma dört, dünyanın yapı taşıdır; evrendir. Söz konusu kavram Türk kültüründe, Okunyev gibi oldukça erken devirlere dayanmaktadır. Hayvan tasvirlerine baktığımızda, onların genelde mücadele ya da kovalama sahnesi olarak medreselerde karşımıza çıktığı görülmektedir. Böyle tasvirlerin medresede betimlenmiş olmaları, bilgeliğin cehaleti karşısında üstünlüğü olarak düşünülebilir. Hayvan mücadele ve kovalama sahneleri, gök-yer kavramlarının yanı sıra zafer-yenilgi, güçlülükzayıflık, erkek-dişi, iyi-kötü, aydınlık-karanlık, vb. zıt kavramlarla da ilişkilendirilmektedir. Tüm bu zıt kavram çiftlerinden olumluya işaret eden ve kazanan, her zaman güçlü özellikleri taşıyan avcı yani yırtıcı hayvan olmuştur. Hayvan tasvirleri ile ilgili tüm sembolizme yine Orta ve İç Asya'daki erken devir Türk sanatında oldukça sık rastlanılmaktadır. Son olarak diyebiliriz ki, Timurlu dönemi mimari yapılarının boyutları, planları ve süslemeleri erken dönemlerden itibaren Türk kültürü ve sembolizmindeki pek çok detayın İslam sanatı ve anlayışı ile sentezlenmiş biçimde devamı olarak karşımıza çıkmaktadır.

\section{Kaynakça}

AKA, İsmail, Timur ve Devleti, Türk Tarih Kurumu Yayınları, Ankara 1991.

AKA, İsmail, "Göçebelikten Rönesansa Bir Türk Devleti: Timurlular”, Türk Kültürü, Y1l XXXVIII, S. 452, Aralık 2000, s. 716-723.

AKA, İsmail, "Timurlular (1370-1506)", Kuruluş ve Çöküş Süreçlerinde Türk Devletleri Sempozyuтu Bildirileri (5-6 Kasım 2007), Sakarya Üniversitesi Yayınları, Sakarya 2008, s. 171-192. 
AKBIYIK, Hayrunnisa A., "Timurluların Bilim ve Sanata Yaklaşımları ve Bazı Son Dönem Sanatkârları", Bilig, S. 30, Yaz 2004, s. 151-171.

AKÇIL HARMANKAYA, N. Çiçek, "Mimar Sinan Camilerinde Sembolizm Üzerine Bir Değerlendirme", Sanat Tarihi Yılliğı, S. 27, Ankara 2018, s. 1-37.

ALTIN, Ara, "Orta Asya Türk Sanatı ile Anadolu'da Selçuklu ve Beylikler Devri Mimarisi”, Mimar Başı Koca Sinan, Yaşadiğı Çă̆ ve Eserleri, Kendi Yayını, İstanbul 1988, s. 3344.

BABAYAR, Gaybullah, Köktürk Kağanlı̆̆ı Sikkeleri Kataloğu, TíKA Yayınları, Ankara 2007.

BALL, Wrawick, "The Remains of a Monumental Timurid Garden outside Herat", East and West, Vol.31, No.1/4, Aralık 1981, s. 79-87.

BAŞKAN, Seyfi, "Semerkand Şah-1 Zinde Yapıları", Vakıflar Dergisi, S. 37, Haziran 2012, 131-166.

BAŞKAN, Seyfi, "Timurlu Çağı Türbe Mimarisi Hakkında”, Sanat Tarihi Dergisi, $\quad$ Cilt XXII, Sayı 1, Nisan 2013, s. 1-23.

BAŞKAN, Seyfi, “Timurlu Mimarlı̆̆ında Çini Süsleme Hakkında Bir Değerlendirme”, Turkish Studies, 9/10, Fall 2014, s. 77-95.

BEAUPERTUIS-BRESSAND, Frédérique, "Alim Emir Yıldıları İlhak Ediyor", Semerkand 1400-1500 Timur'un Vaha Kenti: Bir Imparatorluğun ve Rönesans'ın Kalbi, derl. Vincent Fournau, çev. Ali Berktay, Sena Yayınevi, İstanbul 2005, s. 123-146.

BİLİCI, Z. Kenan. “Asya Rönesansı: Timurlu Çağı'nın Mimarlık Mirasını Anlamak”, Ankara Üniversitesi Sosyal Bilimler Dergisi, S. 9, 2, 2018, s. 5-13.

BURYAKOV, Yuriy F. "Timur, Timurlular ve Bozkırın Türk Göçebeleri”, Türkler Ansiklopedisi, Yeni Türkiye Yayınları, Ankara 2002, s. 534-539.

CANTAY, Gönül, “Emir Timur Devleti’nde Mimari”, Ölümünün 600. Yllında Emir Timur ve Mirası Uluslararası Sempozyumu, 26-27 Mayls 2005, Bildiriler, Doğu Kütüphanesi, İstanbul 2007, s. 235-248.

CEZAR, Mustafa, Anadolu Öncesi Türklerde Şehir ve Mimarlık, Türkiye İş Bankası Kültür Yayınları, İstanbul 1977.

CLAVIJO, Timur Devrinde Kadis'ten Semerkand'a Seyahat, çev. Ömer Rıza Doğrul, Köprü Kitapları, İstanbul 2016.

CLAVIJO, Embassy to Tamerlane: 1403-1406, çev. Guy le Strange, George Routledge and Sons Ltd, London 1928.

ÇORUHLU, Yaşar, Türk Mitolojisinin Anahatları, Kabalcı Yayınevi, İstanbul 2010.

ÇORUHLU, Yaşar, Türk Sanatında Hayvan Sembolizmi, Kömen Yayınları, Konya 2014.

ÇORUHLU, Yaşar, Erken Devir Türk Sanatı (İç Asyada Türk Sanatının Doğuşu ve Gelişimi). Kabalcı Yayınevi, İstanbul 2017. 
DALE, Stephen F., The Garden of the Eight Paradises: Babur and the Culture of Empire in Central Asia, Afghanistan and India (1483-1530), Cambridge University Press, LeidenBoston 2004.

ESİN, E., Orduğ (Başlangıçtan Selçuklulara Kadar Türk Hakan Şehri), Ankara Üniversitesi Basımevi, Ankara 1972.

GOLOMBEK, Lisa - Ebba Koch, "The Mughals, Uzbeks and the Timurid Legacy", A Companion to Islamic Art and Architecture, From the Mongols to Modernism, vol. 2, Ed. Finbarr Barry Flood and Gülru Necipoglu, Wiley Blackwell, Oxford 2017 s. 811845 .

GOLOMBEK, Lisa vd., The Timurid Architecture of Iran and Turan. vol. 1, Princeton University Press, Princeton, 1983.

GOLOMBEK, Lisa. "The Gardens of Timur: New Perspectives", Muqarnas, S. 12, 1995, s. 137-147.

HILLENBRAND, Robert, "Aspects of Timurid Architecture in Central Asia”, Utrecht Papers on Central Asia, Proceedings of the First European Seminar of Central Asian Studies held at Utrecht, 16-18 December 1985, Eds. M.van Damme and H.Boeschoten, Utrecht, 1987, s. 255-286.

İBNI ARABŞAH, Acâibu'l Makdûr (Bozkırdan Gelen Bela), çev. Ahsen Batur, Selenge Yayınevi, İstanbul 2012.

LEONTYEV, N.V. vd., Izvayaniya $i$ steli okunyevskoy kultury, Khakaskoye knijnoye Izdatelstvo, Abakan 2006.

MUKHAMEJANOV, A. R., "Natural Life and the Manmade Habitat in Central Asia", History of Civilizations of Central Asia, The age of achievement: A.D. 750 to the end of the fifteenth century, Volume IV, Part Two, Eds. Bosworth C.E., Asimov M.S., UNESCO Publishing, Paris 2000, s. 275-296.

NECIPOĞLU, Gülru, "Geometric Design in Timurid/Turkmen Architectural Practice", Thoughts on a Recently Discovered Scroll and its Late Gothic Parallels, Iran and Central Asia in the Fifteenth Century, ed. Lisa Golombek - Maria Subtelny, Leiden Brill, 1992, s. 48-66.

O'KANE, Bernard, Timurid Architecture in Khurasan, Mazdâ Publishers, California 1987.

OKTAY ÇEREZCİ, J. Özlem, “Türk Sanatında Yırtıcı Dört Ayaklı Hayvan-Toynaklı Hayvan Mücadelesi Üzerine”, Türk Dünyası Araştırmaları, S. 214, Şubat 2015, s. 65-92.

ORKUN, H. N., Eski Türk Yazıtları, Türk Dil Kurumu Yayınları, Ankara 1987.

PANDER, Klaus, "Timuroğullarının Orta Asya Mimari Sanatına Katkıları", Türkler Ansiklopedisi, Yeni Türkiye Yayınları, Ankara 2002, s. 852-861.

PASKALEVA, Elena, "The Bibi Khanum Mosque in Samarqand: Its Mongol and Timurid Architecture", The Silk Road, Vol. 10, 2012, s. 81-98. 
PUGAÇENKOVA, G. A, "Transoxania and Khurasan”, History of civilizations of Central Asia, The age of achievement: A.D. 750 to the end of the fifteenth century, Volume IV, Part Two, eds. Bosworth C.E., Asimov M.S., UNESCO Publishing, Paris 2000, s. 507-556.

RAMAZANOĞLU, Gözde, Orta Asya'da Türk Mimarisi, Türk Tarih Kurumu Yayınları, Ankara 1998.

ROUX, Jean-Paul, Aksak Timur İslamın Kutsal Savaşçısı, Çev. Ali Rıza Yalt, Milliyet Yayınları, İstanbul 1994.

SEMENOV, A. A., "Gur-i Emir ve Türbesinde Timur'un ve Ahfadının Mezar Kitabeleri”, Makaleler ve İncelemeler (Abdülkadir Inan), Türk Tarih Kurumu Yayınları, Ankara 1968, s. 587-610.

STIERLIN, Henri, Islamic Art and Architecture: from Isfahan to Taj Mahal, Thames and Hudson, London 2002.

ŞAHIN, Mustafa, "Timurlular Döneminde Herât'ta Sivil Mimari”, Studies of the Ottoman Domain, Cilt 6, Say1 11, Ağustos 2016, s. 78-96.

TEKIN, Başak Burcu, Timur Döneminde Mimari Bezeme Olarak Ahşap Kullanımı, (Hacettepe Üniversitesi Sosyal Bilimler Enstitüsü Yayınlanmamış Yüksek Lisans Tezi), Ankara 2000.

TROITSKAYA, T. N. “Tsenı Terzaniya v Skifo-Sibirskom i Hunno-Sarmatskom İskusstve”, Vestnik Arheologii, Antropologii i Etnografii, S.1, 1997, s. 35-37.

Volume 12

Issue 2

A Tribute

to Assoc.

Prof. Dr.

İlknur

Mangir

Karagöz,

YAKUBOVSKIY, Aleksandr, Timur ve Timuriler Devrinde Semerkand, çev. Sabur Rasol, Yayına haz. İlyas Kemaloğlu, Türk Tarih Kurumu Yayınları, Ankara 2018.

YEZDİ, Şerefüddin Ali Emir Timur (Zafernâme), çev. D. Ahsen Batur, Selenge Yayınları, İstanbul 2013.

http://www.iranicaonline.org/articles/herat-iv\#prettyPhoto, (E. T. : 10.01.2020). 


\section{Şekiller}

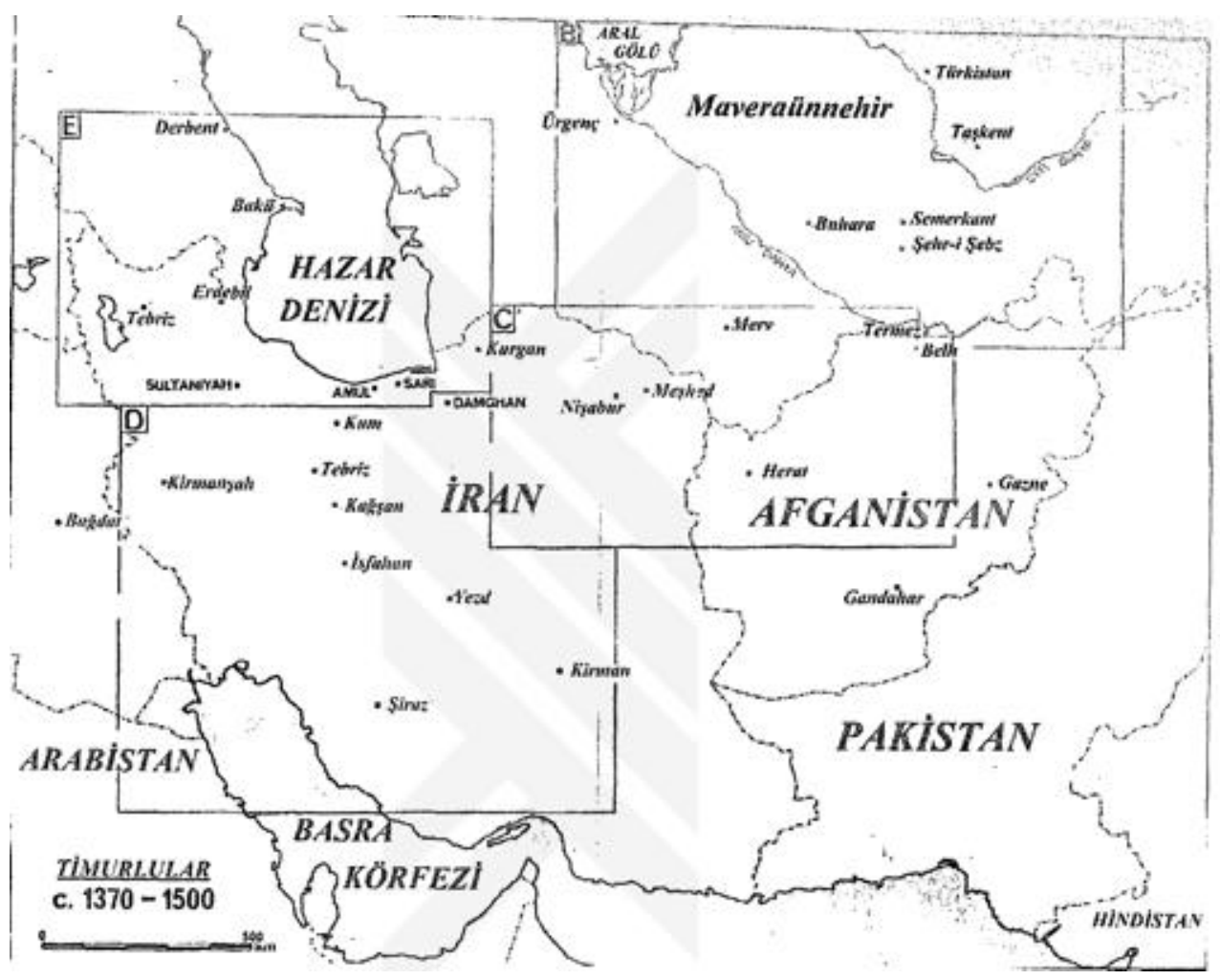

Şekil 1: Timurlu dönemi hakimiyet alanları, (Tekin, levha 2).
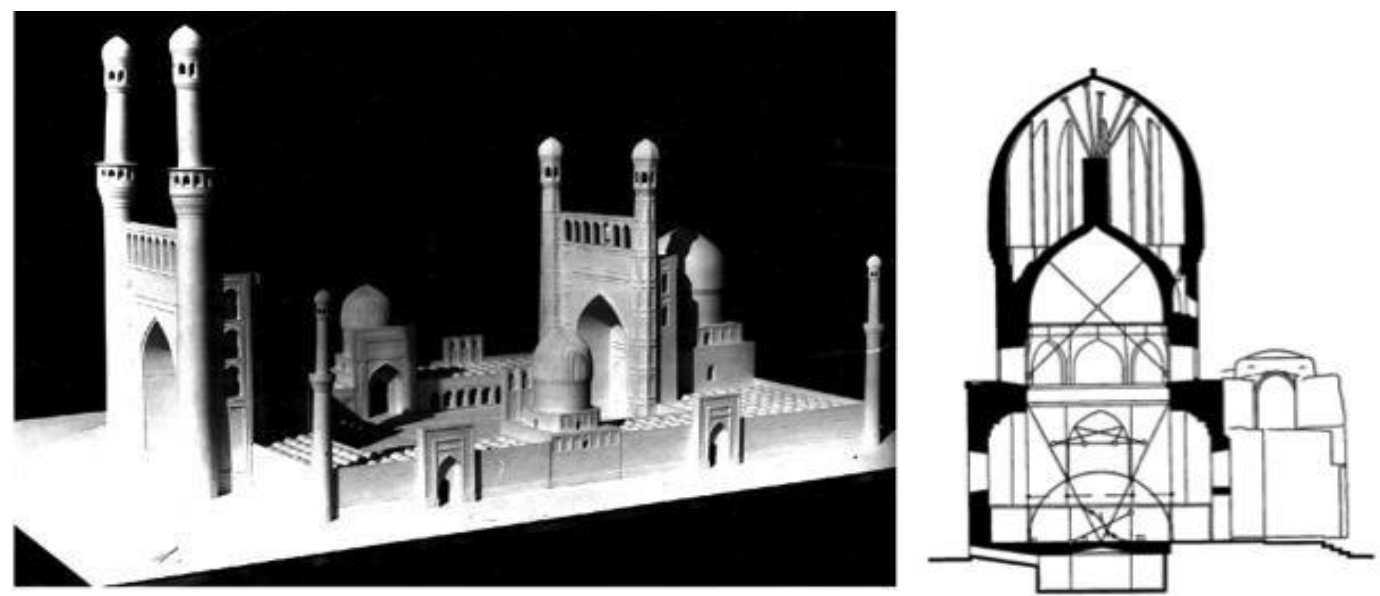

Şekil 2 a-b: Semerkant Mescid-i Cuması ve Gur-i Emir Türbesi, (Golombek - Koch, fig 32.2, 32.4)

Issue 2

A Tribute to

Assoc. Prof.

Dr. Ilknur

Mangir

Karagöz,

April

2020 


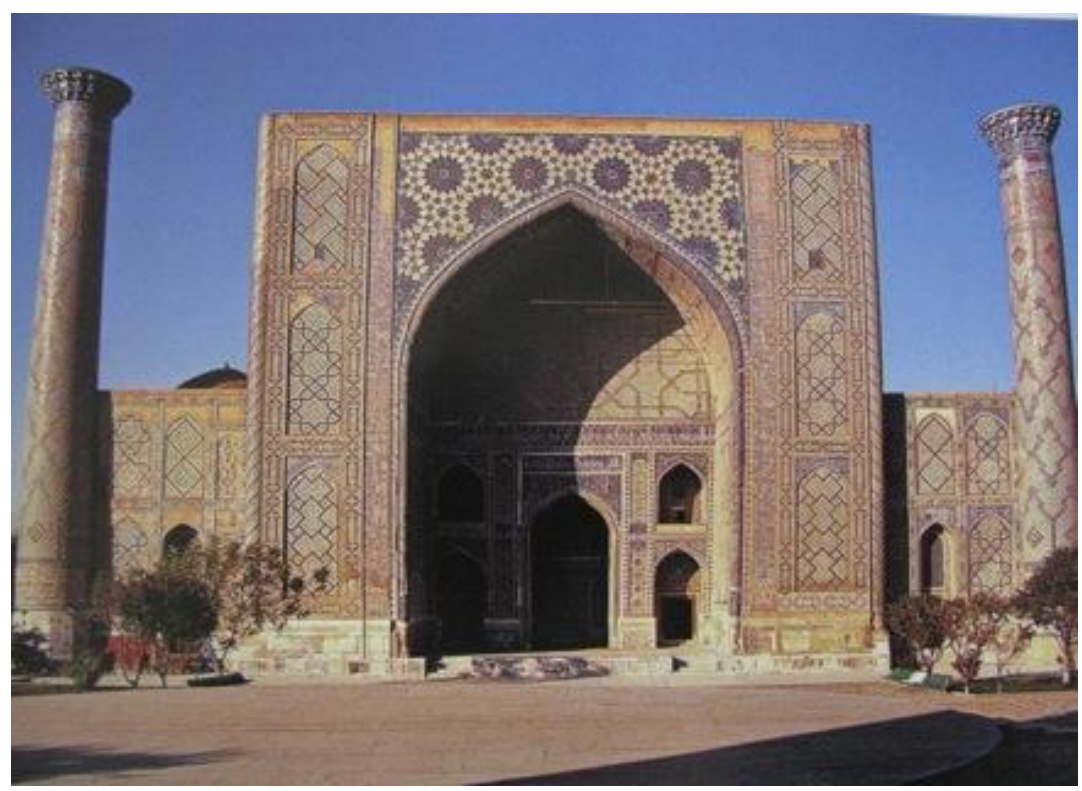

Şekil 3: Semerkant Uluğ Bey Medresesi, (Kök, lev.11).

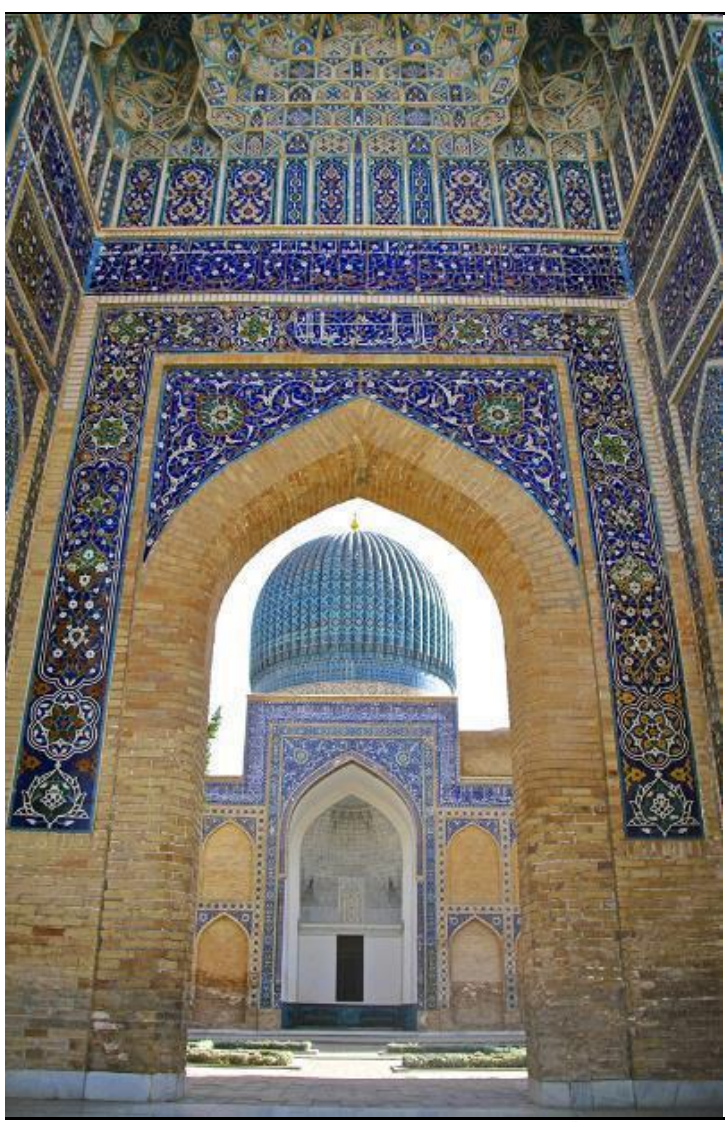

Şekil 4: Gur-i Mir Türbesi, (Başkan, 2014, fot.13). 


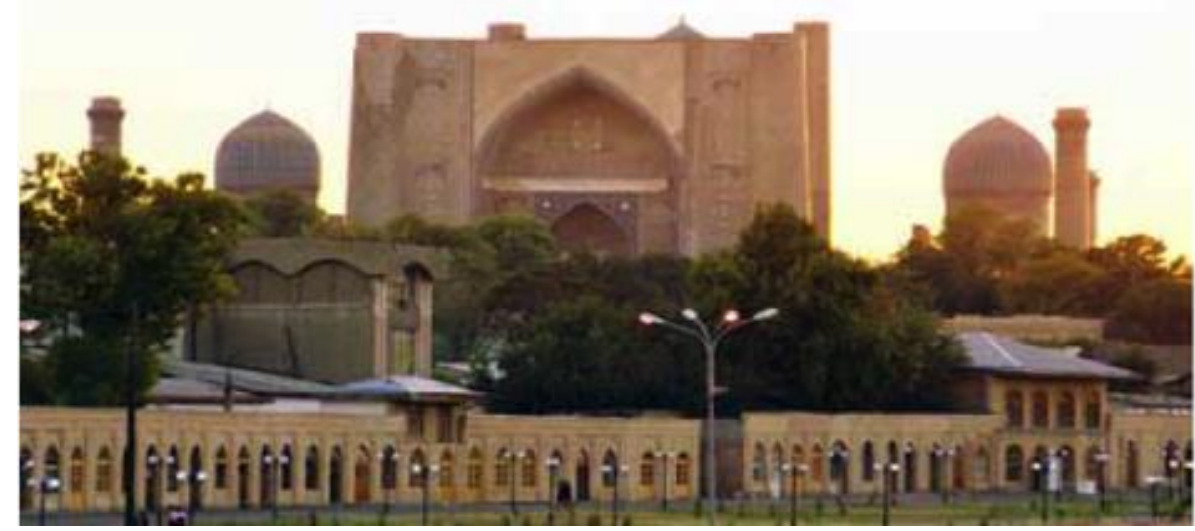

Şekil 5: Bibi Hanım Camii, Semerkand, (Paskaleva, fig.16)

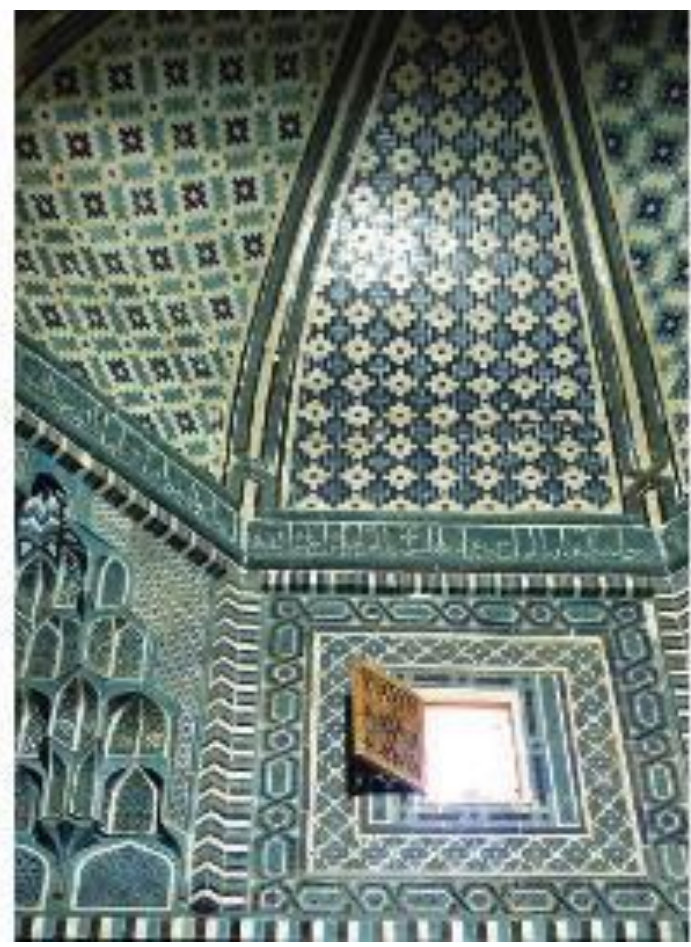

Sekil 6. Kasım b. Abbas Türbesi, kubbe içinden çini süslemeler.

(Başkan, 2012, resim 37).

Volume 12

Issue 2

A Tribute to

Assoc. Prof.

Dr. Illknur

Mangir

Karagöz,

April

2020

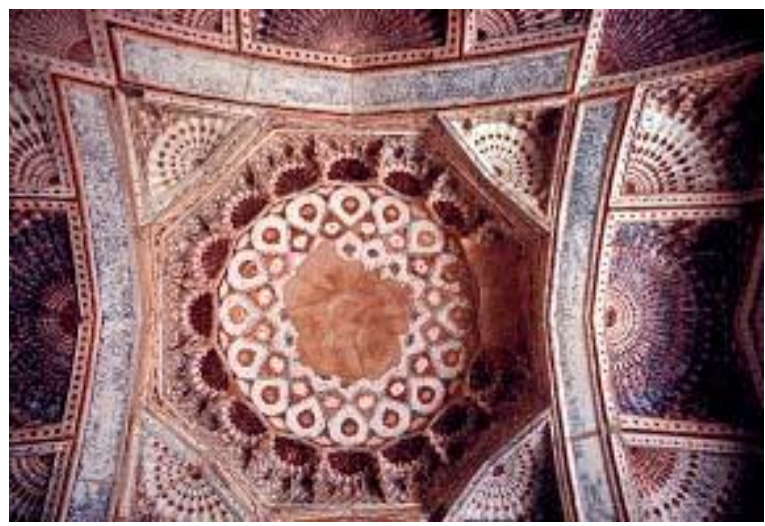

Şekil 7. Herat Gevher Şad Türbesi. (Kök, fot.29). 


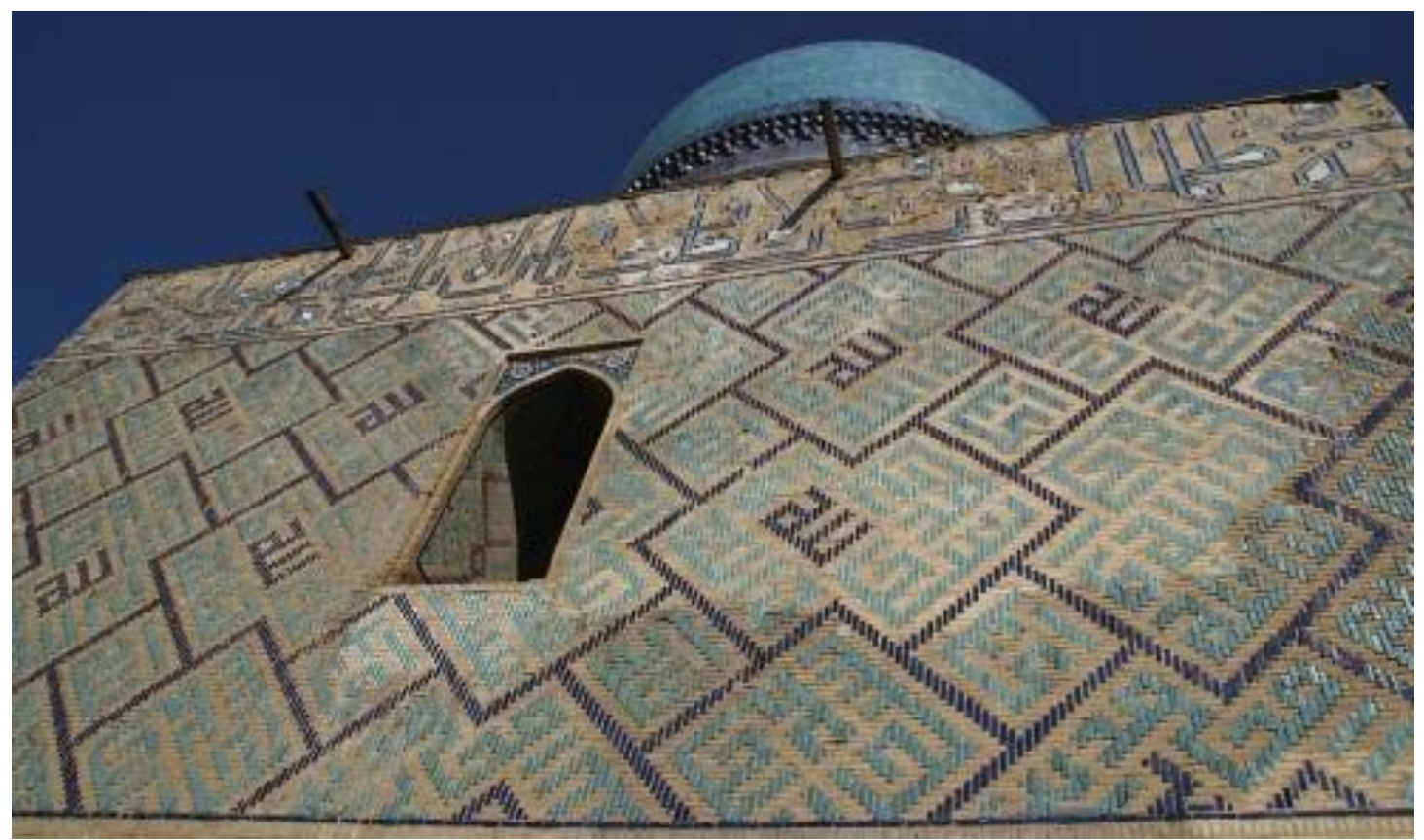

Şekil 8. Bibi Hanım Camii,

(Paskaleva, Fig. 17).

Volume 12

Issue 2

A Tribute

to Assoc.

Prof. Dr.

İlknur

Mangir

Karagöz,

April

2020

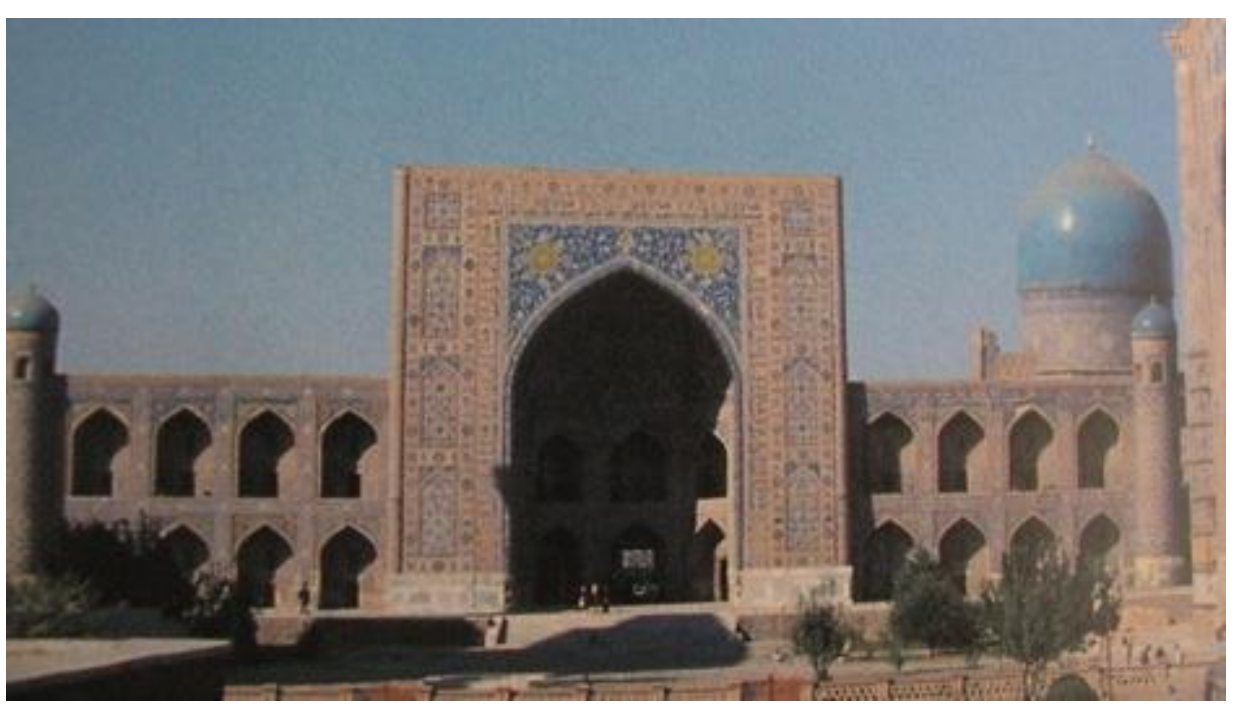

Şekil 9: Tilla Kari Medresesi,

(Stierlin, fot.34). 


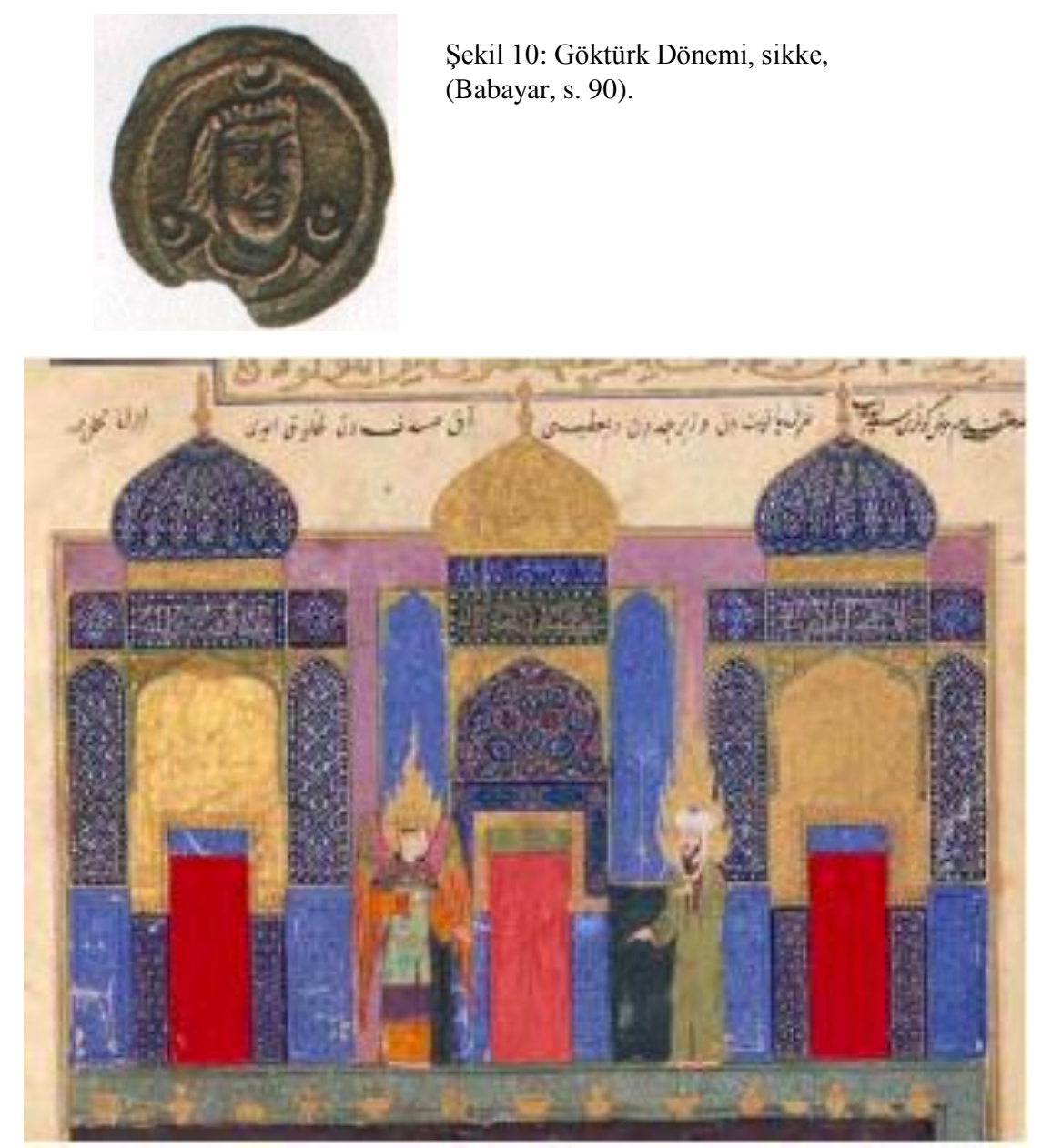

Şekil 11: Miraçnâme, varak 45v. Hz. Muhammed'in Cennet Kapılarına Varışı. Herat 1436-37, (Paskaleva, fig.16).

\section{米 \\ HISTORY \\ STUDIES \\ 720 \\ Volume 12 \\ Issue 2 \\ A Tribute to \\ Assoc. Prof. \\ Dr. İlknur \\ Mangir \\ Karagöz, \\ April \\ 2020}

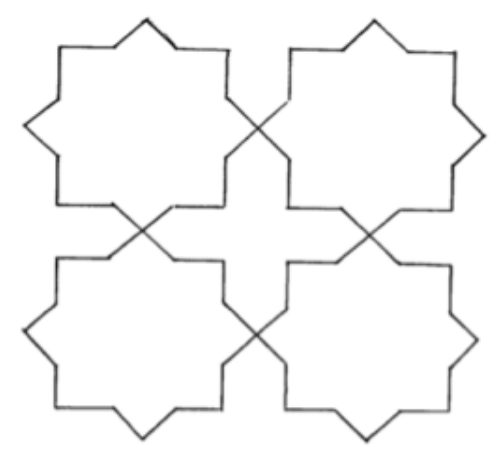

Şekil 12: Gur-i Mir, ahşap kapılarından sekiz kollu yıldız, (Tekin, ç. 83). 


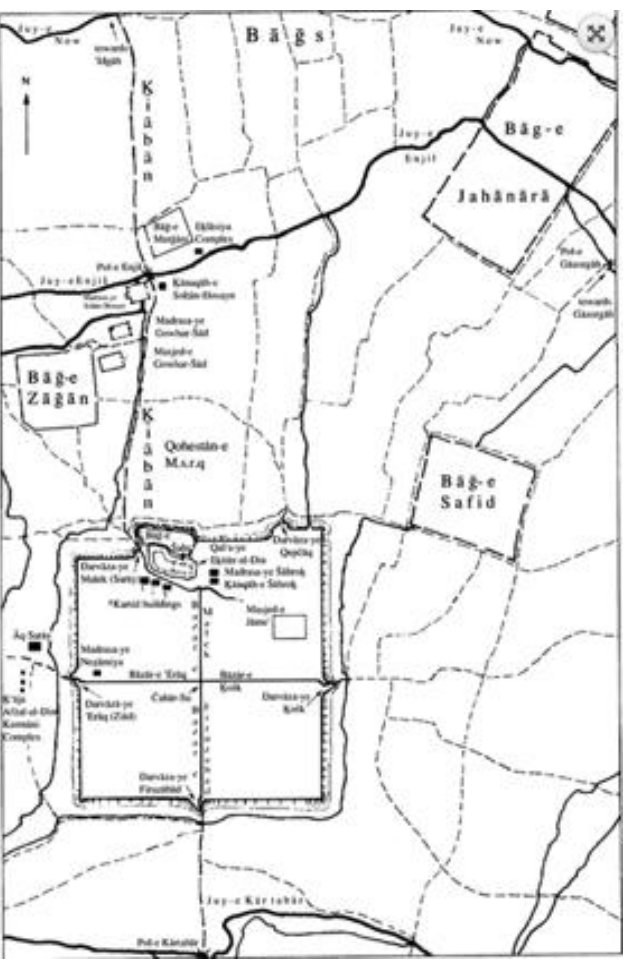

Şekil 13. Timurlu devri, Herat şehri.

(http://www.iranicaonline.org/articles/herat-iv\#prettyPhoto

E. T.: 10.01.2020).

Issue 2

A Tribute

to Assoc.

Prof. Dr.

İlknur

Mangir

Karagöz,

April

2020

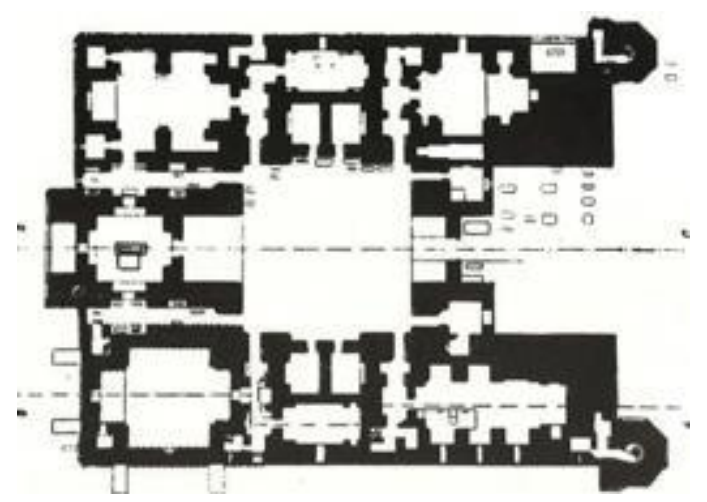

Şekil 14: Hoca Ahmet Yesevi Külliyesi, plan, (Cezar, s.455). 

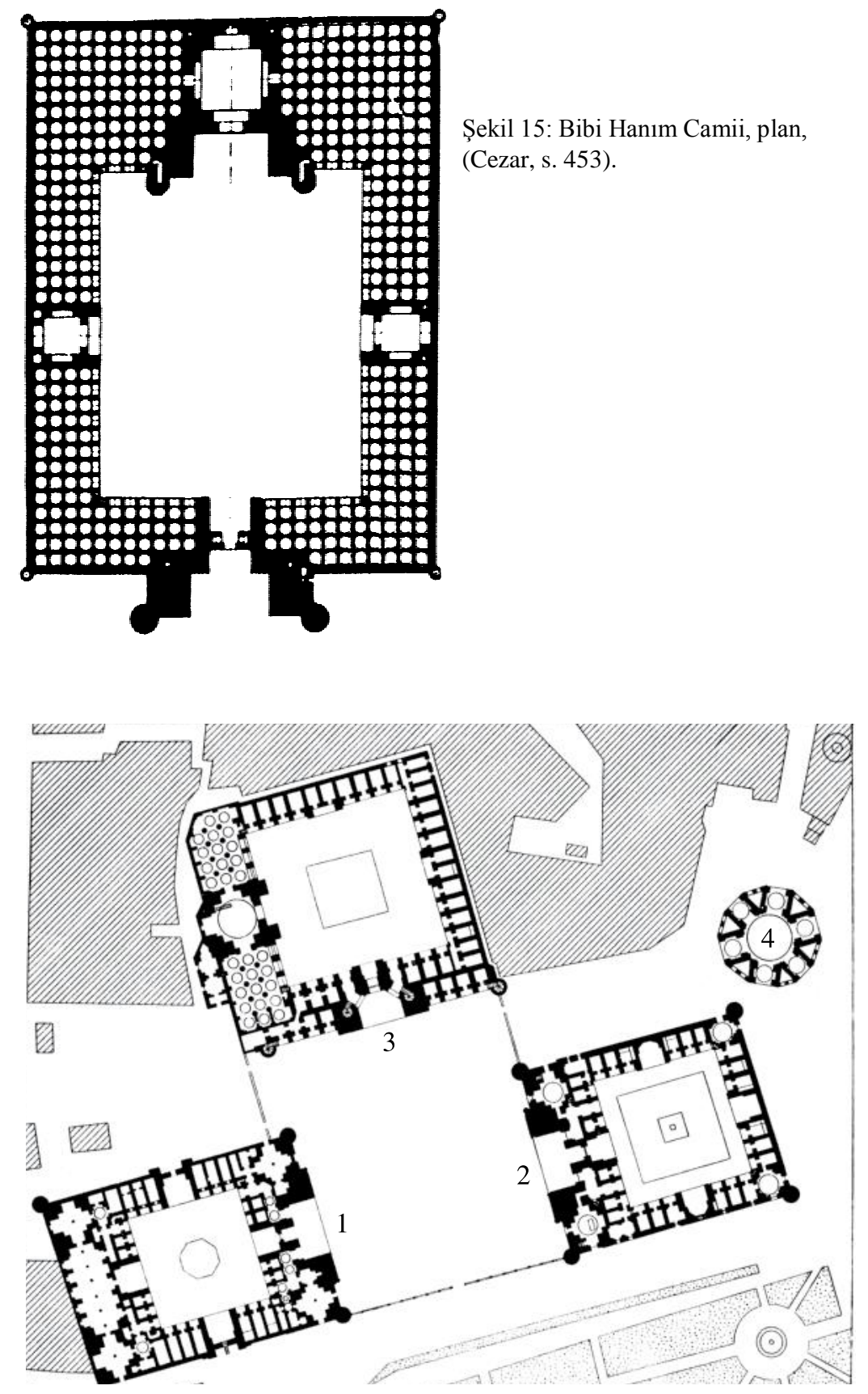

HISTORY

STUDIES

Volume 12

Issue 2

A Tribute to

Assoc. Prof.

Dr. İlknur

Mangir

Karagöz,

April

2020

Şekil 16: Semerkant Registanı, medreseler. (Golombek - Koch, fig. 32).

1. Uluğ Bey Medresesi;

2. Şir Dar Medresesi;

3. Tille Kari Medresesi, 


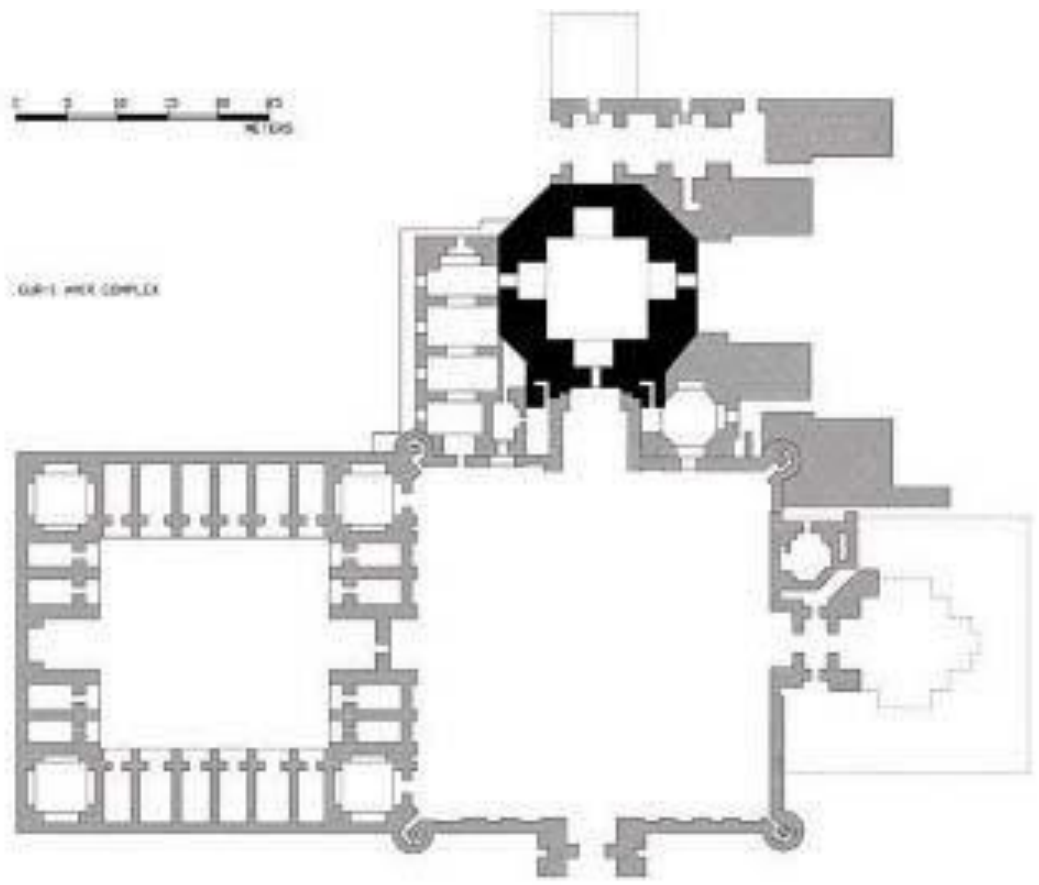

Volume 12

Issue 2

A Tribute

Şekil 17: Gur-i Mir, genel plan,

(Cezar, s. 454).

Prof. Dr.

İlknur

Mangir

Karagöz,

April

2020

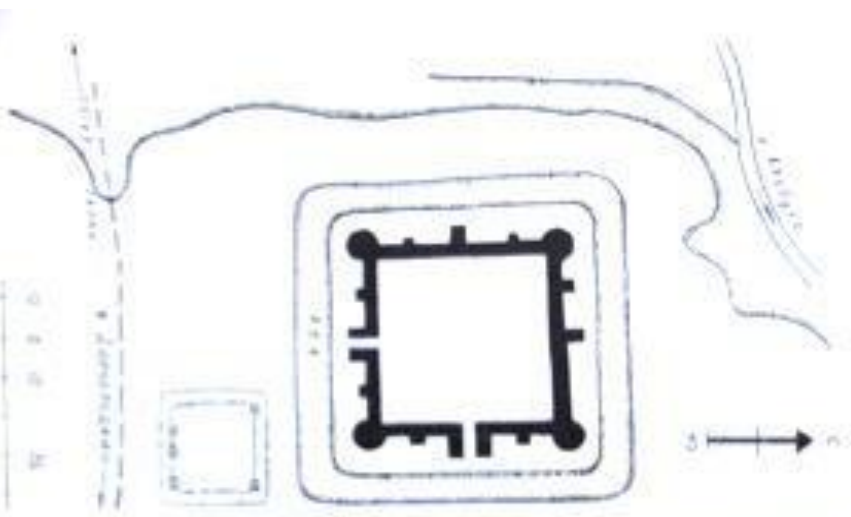

Şekil 18: Şirdak Beg Kalesi,

(Esin, s. 186). 


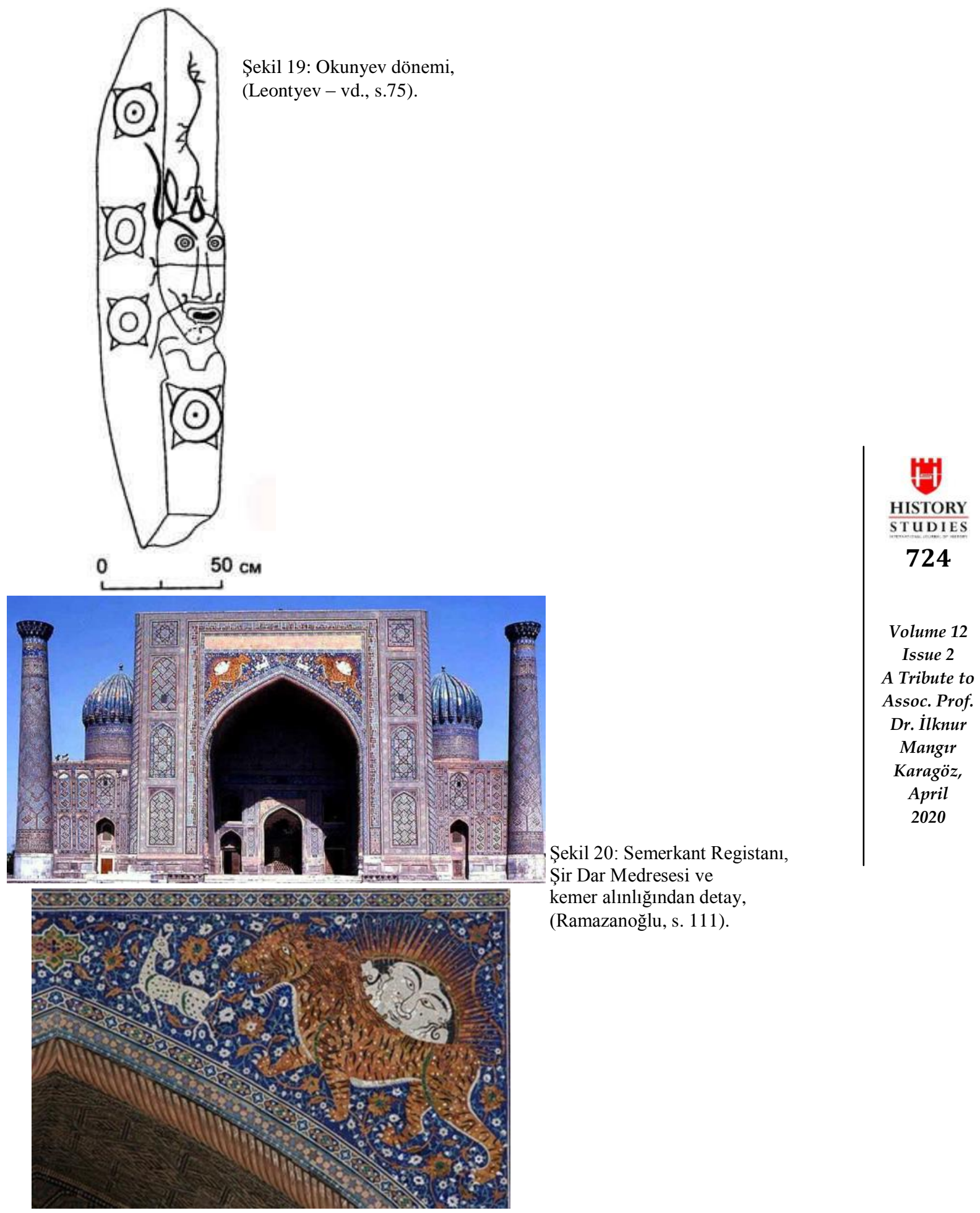




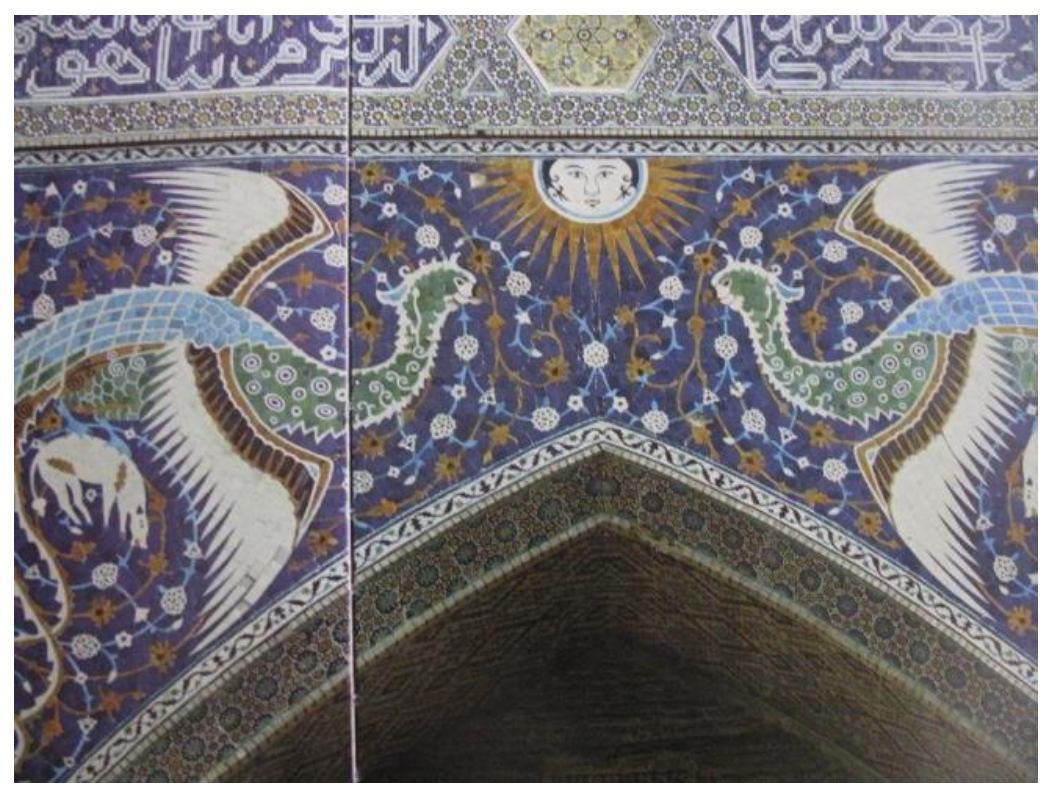

Şekil 21: Buhara Nadir Divan Beg Medresesi,

(Ramazanoğlu, s. 193). 